\title{
EPCS 2000
}

\section{The Increase of the Size of the Shadow \\ Economy of 18 OECD Countries: Some \\ Preliminary Explanations*)}

by

Friedrich Schneider $* *)$

\begin{abstract}
Summary
The latest empirical results of the size of the shadow economy in 18 OECD countries are presented, using the currency demand approach to calculate the shadow economy over time. The results indicate a strong increase in the size of the shadow economy, over the period 1960 to 1998 and for 15 of the 18 investigated OECD-countries the size of the shadow economy is more than $13 \%$ of the GNP for the year 1998. Also an analysis is given about the size of influences of major causes (direct and indirect tax burden and government regulation) on the shadow economy for Austria.

JEL-Class.: H23, H26, H29
\end{abstract}

*) A first version of this paper was presented at the Annual Public Choice Meetings, March 10-12, 2000, Charleston S.C. The author thanks Michael D. Stroup (Austin State University, Texas) for most helpful and stimulating comments.

**) Professor of Economics, Department of Economics, Johannes Kepler University of Linz, A-4040 Linz-Auhof; Phone: +43-732-2468-210/560; Fax.: +43-732-2468-209; email: friedrich.schneider@jk.uni-linz.ac.at 


\section{Introduction}

Over the last two decades a growing concern over the phenomenon of the shadow economy has increased attention among officials, politicians and social scientists. For many countries there are several important reasons, why politicians should be concerned about the size and growth of the shadow economy. Among the most important of these are:

(1) An increase in the size of the shadow economy is mainly caused by a rise in the overall tax and social security payments burden, which may lead to an erosion of the tax and social security bases and finally to a decrease in tax receipts and thus to a further increase of the budget deficit or to further increases of direct and / or indirect tax rates with the consequence of an additional increase in the shadow economy, etc.

(2) Under a growing shadow economy, (economic) policy is based on mistaken „official“ indicators (like unemployment, official labor force, income, consumption), it may to say the least, be wrong in magnitude. In such a situation a prospering shadow economy may cause politicians severe difficulties, because it „provides“ unreliable official indicators; the very direction of intended policy measures may therefore be questionable.

(3) The rise of the shadow economy can be seen as a reaction by individuals being overburdened by state activities (such as high taxes and an increasing number of regulations).

(4) A growing shadow economy may have strong incentive effects to attract workers (domestic and foreign) to work in the shadow economy and to work less (efficiently) in the official economy.

These growing concerns have led many economists to the challenging and difficult task to measure the size and development of the shadow economy, to 
trace back the main causes of it and to analyze the interactions of the official and unofficial economies. In section 2 the latest results of the size of the shadow economies for 18 OECD-countries are shown. In section 3 the development of the size of the shadow economy over time for Austria is presented and in section 4 the influence of a changing tax structure on the shadow economy is investigated. Finally, section 5 summarizes the results of the size of the shadow economy and gives some prospects for future research.

\section{Empirical results of the size of the shadow economy for OECD countries}

As has been shown in the literature ${ }^{1}$ ) the currency demand approach ${ }^{2}$ ) is the most often used method to estimate the shadow economy, it has been applied for most OECD-countries. The results are shown in table 1.

\section{Table 1}

If one compares the results for the latest available year, 1998, it can be seen that Greece (29,6 \%), Italy (27.8\%), Spain (23.4\%), and Belgium (22.6\%) have the largest shadow economies. In the mid-group are Sweden (20.0\%), Norway (19.7 $\%)$, Denmark (18.4\%), Ireland (16.9\%), Canada (15.0\%), France (14.9\%), Germany (14.7\%) and The Netherlands (13.5\%), and at the lower end Austria $(9.1 \%)$, USA ( $8.9 \%)$ and Switzerland $(8.0 \%)$.

Moreover table 1 clearly shows, that the increase of the shadow economy over time is quite remarkable and takes place in all investigated countries. Whereas in

1) Compare e.g. Frey and Pommerehne (1984), Schneider (1994, 1997 and 1999) and Schneider and Enste (2000).

2) The currency demand approach is explained and criticized in section 3 . 
the year 1960 the size of the shadow economy was far below $5 \%$ of GNP, the shadow economy increased in the year 1998 in the countries Australia, Belgium, Canada, Denmark, France, Germany, Greece, Ireland, Italy, the Netherlands, New Zealand, Norway, Spain, Sweden and United Kingdom over $13 \%$ of GNP and in the remaining ones close to $10 \%$. If one considers the development of the shadow economy over time for single countries, the size of the shadow economy for Belgium was in the year $197010.4 \%$ and has more than doubled up to the year 1998 to $22.6 \%$. In the case of Italy the size of the shadow economy was in the year 1970: $10.7 \%$ and reached a size of $27.8 \%$ in the year 1998 - an increase of more than $160 \%$ in 20 years. But also in countries, where the size of the shadow economy is considerably smaller, the increase has been remarkably. If one takes the case of the United States the shadow economy was in the year 1970 $3.6 \%$ and increased up to $8.9 \%$ in the year 1998, an increase of $168 \%$ ! Also the shadow economy of the Netherlands increased from $4.8 \%$ in the year 1970 to $13.5 \%$ in the year 1998 - an increase for more than $181 \%$ ! These results demonstrate that in the examined countries there is a strong increase of the shadow economy over the years 1970 to 1998.

In table 2 it is tried to give one possible explanation of the different sizes of the shadow economies of there OECD countries by comparing the overall tax and social security contributions with the size of the shadow economy of the different countries for the year 1996. ${ }^{3)}$

\section{Table 2}

\footnotetext{
3) In almost all studies the rise of the tax and social security contribution burdens is one of the most important causes of the increase of the shadow economy. Compare for example Frey and Pommerehne (1984), Lipert and Walker (1997), Schneider (1994a, 1994b, 1997, 1999), Thomas (1992, 1999), Tanzi (1999), Giles (1999a) and Schneider and Enste (2000).
} 
With the exception of Spain (shadow economy $22.9 \%$, tax and social security burden $67.2 \%$ ), Greece, Italy, Belgium and Sweden, who have the largest shadow economies in 1996 also have the highest tax and social security burden (72.3, 72.9, 76.0 and 78.6\%), whereas the countries like Switzerland and U.S., who have the lowest overall tax and social security burden (39.7 and 41.4\%) they have the lowest shadow economies with 7.5 and $8.8 \%$, too! Of course, there are exceptions, like the United Kingdom and Austria with a quite high overall tax and social security burden (54.9 and 70.4\%) and a quite low shadow economy (13.1 and 8.3\%), but the overall pictures seems to fit, the higher the overall social security and tax burden, the higher the shadow economy, ceteris paribus. The strong positive relationship that arising tax and social security contribution burdens cause a higher shadow economy, is also demonstrated in figures 2.1. and 2.2.

\section{Figures 2.1. and 2.2}

If one calculates the correlation coefficient between the tax and social security contribution burden and the size of the shadow economy, the coefficient has a value of 0.61 , which is clearly statistically significant from zero. Also other factors have an quite sizeable influence of the shadow economy, like the intensity of regulations (especially labour market regulations), the welfare state and the amount of public sector services. ${ }^{4)}$ Johnson, Kaufmann, and Zoido-Lobatón (1998b) find overall significant and empirical evidence of the influence of (labour) regulations on the shadow economy. In another paper of Johnson, Kaufmann, and Shleifer (1997), empirical evidence supports this finding, it predicts, that countries with more general regulation of the economies tend to have a higher share of the unofficial economy in total GDP; ceteris paribus, an

4) Compare here especially the work of Johnson, Kaufmann and Schleifer (1997), Johnson, Kaufmann and Zoido-Lobatón (1998) and Friedman, Johnson, Kaufmann and Zoido-Lobatón (1999). 
one point increase of the regulation index (ranging from 1 to 5 , with $5=$ the most regulation in a country) is associated with a 8.1 percentage point increase in the share of the shadow economy. In their latest study Friedman, Johnson, Kaufmann and Zoido-Lobatón (1999) reach a similar result: an one point increase of the regulation index (ranging from 1 to 5 ) is associated with a 10 percent increase in the shadow economy of 76 developing, transition and developed countries.

After discussing the size and increase of the shadow economies in terms of value added some first considerations about the shadow labor force are made. In table 3 estimates of the size of the shadow economy labor force in some OECD countries over the period 1974-1998 are shown. ${ }^{5)}$

\section{Table 3}

The figures provide a rough estimate about the size of the "shadow labor force", for example the results for Denmark indicate that the population engaged in the shadow economy ranges from $8.3 \%$ (of the total labor force) in 1980 to $15.4 \%$ in 1994. In Germany this figure rose from 8\% - 12\% (1974-1982) to 22.0\% (199798). In other countries the "shadow economy labor force" is quite large, too: in Italy between 30.0 and 48.0\% (1997/1998), Sweden 19.8\% (1997), France 6-12\% (1997/1998). In the European Union at least 10 million people are engaged in shadow economic activities and in all OECD countries about 16 million work black. These figures demonstrate that the shadow economy labor

\footnotetext{
5) The "shadow economy labour force" can be calculated in two ways: 1. In surveys covering a whole country people were asked about the amount of hours they work in the shadow economy. These figures are used to calculate a total amount of hours work in the shadow economy in a country and from this figures "full time shadow economy workers" can be claculated (in persons). Of course it is obvious that there actually exists only a tiny fraction of full time shadow economy workers, the calculation is only done to give an overall impression, how large the shadow economy labour force would be. The $2^{\text {nd }}$ method starts from the value added estimates of the shadow economy, subtracts from these the value added of all material used in the shadow economy. Making the assumption of an average shadow economy wage rate the amount of hours worked in the shadow economy can be calculated again and from this figure the shadow economy labour force (in persons).
} 
market is lively and may provide an explanation, why, for example in Germany one observes such a high and persistent unemployment in the "official labor" market.

In order to study the increase of the shadow economy in more detail, in the next section the development of the shadow economy over time for one country, Austria, is investigated. Austria was chosen, because there is available data on various kinds of direct and indirect tax burdens as well as data on the intensity of regulation. For Austria it can additionally investigated, which of the major causes (tax pressure, regulation, etc.) contributes most to the size of the shadow economy.

\section{Empirical results of the size of the Austrian shadow economy over time}

The method chosen for estimating the shadow economy in Austria over time is the currency demand approach. This approach assumes that shadow (or hidden) transactions are undertaken in the form of cash payments, so as to leave no observable traces for the tax authorities. ${ }^{6}$ )

An increase in the size of the shadow economy will therefore increase the demand for currency. To isolate the resulting „excess“ demand for currency, an equation for currency demand is econometrically estimated over time, with controls for all possible conventional factors, such as the development of income, payment habits, interest rates, and so on. Additionally, such variables like the tax

6) The currency demand approach was first used by Cagan (1958), who calculated a correlation of the currency demand and the tax pressure as one cause of the shadow economy for the United States for the period 1919 to 1955. 20 years later, Gutmann (1977) used the same approach, but did not use any statistical procedures; instead he „only“ looked at the ratio between currency and demand deposits for the years 1937 to 1976. Cagan's approach was further developed by Tanzi $(1980,1983)$ who estimated a currency demand function for the United States for the period 1929 to 1980 in order to measure the shadow economy. 
burden and government regulations, which are assumed to be important major factors that cause people to work in the shadow economy, are included in the estimation equation. The "excess" increase in currency, which is the amount unexplained by the conventional or normal factors (mentioned above), is then attributed to such variables as rising tax burden and regulations. Figures for the size and development of the shadow economy can be calculated in a first step by a comparison of the difference between the development of currency, when the tax burden and government regulations are held at their lowest values, and the development of currency with the current (much higher) burden of taxation and government regulations. Assuming in a second step the same income velocity for currency used in the shadow economy as for legal M1 in the official economy, the size of the shadow economy can be computed and compared to the official GDP.

The currency demand approach is one of the most commonly used. Up to 1998 it has been applied to 23 OECD-countries ${ }^{7}$, , but has nevertheless been criticized on various grounds. ${ }^{8}$ The most commonly raised objections to this method are stated below: The first objection relates to the fact that not all transactions in the shadow economy are paid in cash. Isachsen and Strom (1985) used the survey method to discover that in Norway in 1980 roughly $80 \%$ of all transactions in the hidden sector were paid in cash. The size of the total shadow economy (including barter) may thus be even larger than previously estimated. The second objection is that most studies consider only one particular factor, the tax burden, as a cause of the shadow economy. Other causes (such as the impact of regulation, the complexity or visibility of the tax system, taxpayers' attitudes to the state, ,tax morality“, and so on) are not considered because time series data of these variables is not available for most countries. If, as seems likely, these other

7) Compare, e.g., Boeschoten and Fase (1984), Schneider (1994, 1999) and Schneider and Enste (2000).

8) See, e.g., Garcia (1978), Blades (1982), Frey and Pommerehne (1984), Klovland (1984), Kirchgässner (1983, 1984), Weck (1983), Schneider (1986, 1994), Thomas (1986, 1992 and 1999) and Pozo (1996). 
factors also have an impact on the extent of the hidden economy, it might be larger than reported in most studies. ${ }^{9}$ ) A third objection against this approach at least, when applied to the United States, is discussed by Garcia (1978) and Park (1979). They point out that increases in the ratio of currency and demand deposits are due largely to a slow-down in demand deposits rather than to an increase in currency caused by activities in the shadow economy. A fourth objection is that the U.S. dollar is used as an international currency, so that Tanzi should have considered (and compensated for) the amount of U.S. dollars held in cash abroad. Finally, Frey and Pommerehne (1984) claim that Tanzi's parameter estimates are not very stable. ${ }^{10}$ ) A fifth objection against this procedure, as applied in most studies, is the assumption that the velocity of money in both types of economy is the same. As Klovland (1984) argues for the Scandinavian countries, there is already considerable uncertainty about the velocity of circulation of currency in the official economy; the velocity of currency in the hidden sector is even more difficult to estimate. Without knowledge about the velocity of currency in the shadow economy, one has to accept the assumption of currency velocity in both sectors to be the same. ${ }^{11}$ ) Finally, a sixth objection is that the assumption of no shadow economy in a base year is open to criticism. Relaxing this assumption would again imply an upward adjustment of the figures attained in the bulk of the studies already undertaken.

Having just discussed its major weakness, the question may arise as to why I have still chosen this approach. The answer is the following:

9) One (weak) justification for the use of the tax variable only is that this variable has by far the strongest impact on the size of the shadow economy in all studies known to the author. The only exception is the study by Frey and Weck-Hannemann (1984), in which the variable ,tax immorality“ has a quantitatively larger and statistically higher influence in the model than the direct tax share. In a study of the U.S. shadow economy by Pommerehne and Schneider (1985), where data on various tax measures as well as on regulation, tax immorality and minimum wage rates are available, the tax variable has a dominating influence and contributes roughly 50 - $60 \%$ to the size of the shadow economy.

10) In studies for European countries, however, Kirchgässner (1983, 1984) and Schneider (1986) reach the conclusion, that the estimation results for Germany, Denmark, Norway and Sweden are quite robust, when using this approach.

11) Hill and Kabir (1996) and Giles (1999a, 1999b) undertake simulations varying the velocity of money and found different sizes of the shadow economy for Canada. 
(i) Concerning the monetary sector there is reliable time-series data for Austria for the period 1956 to 1998 , and also time-series data for the different measures of the tax burden, the complexity of the tax system and the intensity of regulation, which are major causes of the shadow economy; and

(ii) the currency demand approach has been the most widely used so that comparisons to other countries can be made. In applying the currency demand approach, I follow the procedure developed by Klovland (1984). His basic model relates the stock of currency demanded by the public (outside banks) to the price level, the volume of transactions in the regular economy and the interest rate as a measure of the opportunity costs of holding currency. ${ }^{12}$ ) I extend the procedure developed by Klovland by adding a close substitute for cash money, the Eurocheque system (negative sign expected) ${ }^{13}$ ) and by including more possible causes, why people might work in the shadow economy.

As argued elsewhere, the following four types of causes for working in the shadow economy are distinguished: ${ }^{14}$,

(i) The burden of total direct taxation (DIRT), both average and marginal ${ }^{15}$, with

DIRT $_{\mathrm{t}}=$ TATRY $_{\mathrm{t}}+$ AMTRYt, where

TATRY $_{\mathrm{t}}=$ total average tax rate (including social security payments) on wage income in the year $t$ and

12) In order to avoid the difficult problem of money illusion, I deflated the dependent variable, currencypercapita, and the independent variables, consumption and interest rates, with the GDP-deflator. The interest rate on bonds prooved to be the best measure for the opportunity cost of holding currency. For further empirical investigations using different deflators and different opportunity cost measures, see Hofreither and Schneider (1987, 1989) and Schneider (1994).

13) As a proxy for the total value of Eurocheques and Eurocheque-cards (as a substitute of money) in a year, the number of valid Eurocheque-cards held by the public is used. However, since 9 years one can get easily cash using the Eurocheque-card at an automatic money machine, so that the possibility to get cash increased severely with the consequence that the negative expected sign may be questionable.

14) Compare, for example, Pommerehne (1983, 1986), Hofreither and Schneider (1987), Neck, Schneider and Hofreither (1989), Schneider (1994, 1999) and Tanzi (1999). 
AMTRY $_{\mathrm{t}}=$ average marginal tax rate on wage income in the year $\mathrm{t}$. A rising burden of direct taxation provides a strong incentive to work in the shadow economy; positive sign expected.

(ii) The burden of indirect taxation (INDT), which is defined as the percentage ratio of the sum of all indirect taxes to gross domestic production net of indirect taxes. Again a rising burden of indirect taxation provides a strong incentive to work in the shadow economy; positive sign expected.

(iii) The complexity of the tax system (COMTX) ${ }^{16}$, which following Wagner (1976) and Clotefelter (1976, 1983), is defined with the help of the Herfindahl-Hirschman concentration measure:

$$
\operatorname{COMTX}_{t}=\sum_{i=1}^{m}\left(R E V_{i t}\right)^{2}+\sum_{j=1}^{n}\left(\operatorname{EXEM}_{j t}\right)^{2}
$$

where

$\mathrm{REV}_{\text {it }}$ equals the $\mathrm{i}$-th revenue share of the total revenue amount for all $\mathrm{m}$ revenue items in a year $\mathrm{t}$;

EXEM $_{\mathrm{jt}}$ equals the $\mathrm{j}$-th tax exemption of the total tax exemptions $\mathrm{n}$ in a year $\mathrm{t}$, which refer to direct and indirect taxes and for statistical reasons REV and EXEM are combined into one variable.

Thus COMTX is equal to 2 if only one revenue source exists in a year $t$ and if there are no tax exemptions. In this case, the tax system is highly simple and every change will be immediately recognized by the taxpayer, e.g., an increase in the tax burden will immediately lead to more shadow economy activities. As the number of revenue sources and tax exemptions increases, the tax system becomes more and more complex. In this case, a tax increase

15) Most studies stress that both average and marginal tax rates induce people to work in the shadow economy; compare the references in Schneider (1994).

16) For a theoretical underpinning why this variable is included, compare Neck and Schneider (1993), where a simple theoretical microeconomic model of household behavior is formulated where the household can participate in the official and shadow economy. Using comparative statistics, Neck and Schneider show 
is much less recognizable (,felt" much less) by the taxpayer and hence leads to a lower increase in shadow economy activities than under an extremely simple tax system. ${ }^{17}$ ) Moreover, the more "legal" tax loopwholes and tax exemptions are created the lower is the incentive to work in the shadow economy (ceteris paribus); positive sign expected.

(iv) The intensity of regulations (REG), as proxy for all state regulatory activities, which is defined a the stock of all existing and enforced laws concerning federal, state and local regulatory activities. ${ }^{18}$ ) It is assumed, too, that increases in the burden of regulation provide a strong incentive to work in the shadow economy; positive sign expected.

The estimation results of the currency demand functions are shown in table 4 .

\section{Table 4}

All coefficients of independent variables have the theoretically expected signs, are statistically significant at the $95 \%$ confidence level. Also the other teststatistics show satisfactory results; especially the „true“ ex-post forecast for the period 1990 to 1998 indicates that the major independent factors in the currency demand function are included. ${ }^{19}$ )

As in most studies for Austria's neighboring countries as well as for the Scandinavian countries it is assumed, that there would have been no shadow

that the complexity of the tax system affects participation in the shadow economy negatively, i.e. a more "complex" tax system implies, ceteris paribus, a smaller labor supply in the shadow economy.

17) There is an extensive literature on this type of ,fiscal illusion“, compare, e. g. Pommerehne (1983, 1986).

18) Regulatory activities are here defined in the areas of foreign labor, social security, working hours and other working conditions. The author is aware that this is an extremely crude measure, which is open to severe criticism, but I do not know any better measure, which is available on a time series basis.

19) Some further results (e.g., transforming the dependent variable into first differences) are available from the author upon request. The log transformation of the dependent and independent variables seems to be the best functional form. 
economy if the direct and indirect tax burdens and the amount of regulation had remained at their historical minimum from 1956 until 1998. Keeping these variables at their minimum level in the year 1956, the „normal“ (without shadow economy) level of currency holdings is calculated by undertaking a dynamic simulation. The difference between the actually observed and the simulated currency holdings is assumed to reflect the amount of currency used for shadow economy transactions. Assuming the same velocity for currency used in the shadow economy as for legal M1 in the official economy, the size of the shadow economy is computed and compared to the official GDP. ${ }^{20}$ ) Table 5 shows the results for the absolute values and the growth of the Austrian shadow economy from 1965 to 1998. The Austrian shadow economy increased more or less steadily and reached a peak value in 1998 with 9.12 percent of official GDP. The conclusion by Franz (1985) and Mooslechner (1985) that the shadow economy did not grow from 1976 to 1982 is not supported by these findings. ${ }^{21}$ )

\section{The influence of changing tax structures on the Austrian shadow economy}

Table 5 indicates that the Austrian shadow economy has more or less grown steadily in the course of time.

\section{Table 5}

This is surprising as there had been major changes of the direct and indirect tax rates and of tax structures during the period 1965 to 1998. In the following, it is

\footnotetext{
20) Because of a complete lack of knowledge about the velocity of money in the shadow economy, this assumption is made here as in most other studies using this approach (e.g., Tanzi, 1980, 1983; Kirchgässner, 1983, 1984; Iachsen and Strom, 1985; Schneider, 1986, 1994) However, the calculation of the shadow economy using different velocities of money is quite sensitive compare the latest work by Hill and Kabir (1996) and Giles (1999a, 1999b) for Canada.

21) Due to the different specification and the inclusion of the additional independent variables as causes for working in the shadow economy, the results in table 3 differ from the results in Hofreither and Schneider $(1987,1989)$ and Schneider, Hofreither and Neck (1989).
} 
investigated what influences had the effects of these tax changes on the development of the shadow economy and test the hypothesis on the complexity of the tax system, considering three cases ${ }^{22)}$ :

(i) $1972 / 73$

- the introduction of the value-added tax, a rate of $16 \%$ (1.1.1973),

- switch from family (joint) to individual income taxation, and

- additional tax exemptions to stimulate investment and accumulation of capital.

(ii) $1983 / 84$

- increase of most indirect tax rates (e.g., value-added tax from 18 to $20 \%$, value-added tax on luxury goods from 30 to $32 \%$, etc.),

- new tax on interest rates, and

- tax exemptions to stimulate venture capital.

(iii) $1988 / 89$ (major income tax reform)

- considerable reduction of all marginal tax rates on income, e.g., from 62 to $50 \%$ (top marginal tax rate),

- reduction of the number of income-tax rates from 10 to 5 , and

- decrease in the average tax rates on capital gains and profits and simplification of the system.

The influence of these three major tax changes on the development of the shadow economy is shown in Table $6 .{ }^{23)}$

22) In the following, only the most important tax rate and structure changes are discussed; for detailed information, see Bös (1975), Genser and Holzmann $(1987,1990)$.

23) The influences of the tax changes (i) to (iii) are reflected in changes of the yearly values of the three independent tax variables DIRT, IND and COMTX. The calculations in table 6 are done using the estimated coefficients and the values of the independent variables to calculate the values they contribute to the shadow economy of the year of the tax reform $t$ and of the year $t+1$. 


\section{Table 6}

If one first considers case (i), the changes in direct taxation (e.g., switch from family to individual taxation) had the strongest effect on the shadow economy (42 $\%$ of the increase of the shadow economy were caused by these changes). The introduction of the highly simple value-added tax (compared to the old turnover tax) had a stronger effect on the reduced complexity than on the rise in the indirect tax burden. Switching to case (ii), the "cold progression effect" of income taxation dominated the increase in the rates of a number of indirect taxes. Whereas the first was responsible for $58.4 \%$ of the increase of the shadow economy, raised indirect taxes contributed only 40.5\%. However, most interesting is case (iii), the major tax reform in 1989. Ceteris paribus, the considerable reduction in the direct marginal and average tax burden would have decreased the shadow economy by 1.15 Bill.AS (a reduction of $2.5 \%$ of the shadow economy of 46.37 Bill.AS in 1988). However, the negative effect of the decreased personal income tax rates on the shadow economy is more than offset by the strongly reduced complexity of the tax system. Also the increased

regulation intensity compensates the negative effect of the reduced income tax rates as well.

Table 7 shows the break down of the four causes in percent responsible for the size and growth of the shadow economy. ${ }^{24)}$

\section{Table 7}

\footnotetext{
24) The calculations of the relative influencies of the four causes, which contribute to the Austrian shadow economy, are done in the following way: The total influence of the four independent variables DIRT, IND, COMTX and REG are calculated for every year in total and this sum is normalized to 100 . Then the relative weights (adding up to 100) of the independent variables are calculated for each year. 100.
} 
If one first considers the direct tax burden, it has by far the biggest influence of the whole period; however, it is a strongly declining one: up to the year 1977 roughly $50 \%$ of all shadow economy activities were caused by the burden of direct taxation, but in the year 1995 this impact hat diminished to $29 \%$. Since then, however, if increased again to $29.5 \%$ (year 1998) due to the necessety to fullfill the Maastricht-criteria, the Austrian government increased direct tax rates. The opposite trend holds for the influence of the indirect tax burden. Whereas in the sixties "only" $12 \%$ of shadow economy activities were caused by this factor, in the years 1997 and 1998 the influence had risen to $26.7 \%$ and 26.8, respectively. The influence of the complexity of the tax system on the shadow economy also declined compared with the seventies; in the sixties we had quite a simple tax system causing $25 \%$ of all shadow economy activities. This influence diminished to $17.7 \%$ in $1997-98$. On the other hand, we can observe a strong increase in the percentage share of the shadow economy due to the intensity of regulation. In the sixties and seventies this factor caused "only" $10-12 \%$ of all shadow economy activities, but increased to 26.0-26.3\% in the years 1997 and 1998.

These findings confirm the theoretically derived hypothesis about the influence of the complexity on the shadow economy: The decline of the direct tax burden in 1989 had a negative effect on the size of the shadow economy, but it had been offset by a decrease in complexity of the tax system and an increase in regulations (especially in the labor market).

\section{Summary and future research areas}

If one wants to calculate the size of the shadow economy, one realizes that there are many obstacles to be overcome to measure its size and to analyze the 
consequences on the official economy, but some progress has been made. In this paper it has been shown that, though it is difficult to estimate the size of the shadow economy, it is not impossible. I have demonstrated that with the currency demand approach some insights can be provided about the size and development of the shadow economy of the OECD-countries. The general impression from the results of the two methods is that the shadow economy is sizable. For 15 of the 18 investigated OECD-countries the estimate of the studies shown in table 1 for the year 1998, demonstrate that its size is more than $13 \%$ of GNP. As it has already been argued, there is no „best“ or commonly accepted method; each approach has its specific strengths and weaknesses and each specific insights and results. Although the different methods provide a rather wide range of estimates, there is general agreement that the size of the shadow economics for the OECDcountries has been strongly growing over the recent decades. This has been especially demonstrated for Austria, where the shadow economy increased from 12,02 (1.73\% official GNP) billion Austrian shillings in the year 1975 to 123,62 (9.12\% of official GNP) billion shillings in the year 1998.

The next step is to analyze in much greater detail the effects of changing policy means on the development of the shadow economy. When the government changes the tax structure like a decrease of direct tax burden one would expect that the shadow economy would decrease. However, I observed in the period from 1989 to 1998 that even, when a major tax reform with significant lower tax rates had been undertaken, the shadow economy is still increasing, because other important factors, why people work in the shadow economy, like regulation, have increased during this time. Hence, the effect of a lower direct tax burden was more than offset by the increased regulation.

In general these results should be seen as a first step to study the interactions between the official and the shadow economy. In the next steps it should be 
worked out in a much more precise way how the shadow economy is also influenced by non-economic influences (like the tax morale and peoples' attitude towards the state) and what consequences these influences have on the official economy. 
Table 1: The Development of the Size of the Shadow Economy in Selected OECD Countries Over Time Applying the Currency Demand Approach

\begin{tabular}{|l|c|c|c|c|c|c|c|c|}
\hline \multirow{2}{*}{ OECD-Countries } & \multicolumn{7}{|c|}{$\begin{array}{c}\text { Size of the Shadow Economy (in \% of official GDP) } \\
\text { Using the Currency Demand Approach in the Year }\end{array}$} \\
\cline { 2 - 10 } & $\mathbf{1 9 6 0}$ & $\mathbf{1 9 7 0}$ & $\mathbf{1 9 8 0}$ & $\mathbf{1 9 9 4}$ & $\mathbf{1 9 9 5}$ & $\mathbf{1 9 9 6}$ & $\mathbf{1 9 9 7}$ & $\mathbf{1 9 9 8}$ \\
\hline Australia & - & - & - & 13.0 & 13.2 & 14.0 & 13.9 & 14.1 \\
\hline Austria & 0.4 & 1.8 & 3.0 & 6.7 & 7.3 & 8.3 & 8.9 & 9.1 \\
\hline Belgium & - & 10.4 & 16.4 & 21.4 & 21.6 & 21.9 & 22.4 & 22.6 \\
\hline Canada & - & - & $10.1-11.2$ & 14.6 & 15.0 & 15.1 & 14.8 & 15.0 \\
\hline Denmark & $3.8-4.8$ & $5.3-7.4$ & $6.9-10.2$ & 17.6 & 18.1 & 18.3 & 18.1 & 18.4 \\
\hline France & - & 3.9 & 6.9 & 14.3 & 14.8 & 14.9 & 14.7 & 14.9 \\
\hline Germany & $2.0-2.1$ & $2.7-3.0$ & $10.3-11.2$ & 13.1 & 13.9 & 14.5 & 15.0 & 14.7 \\
\hline Greece & - & - & - & 26.0 & 26.6 & 28.5 & 28.7 & 29.0 \\
\hline Ireland & - & 4.3 & 8.0 & 15.3 & 15.6 & 15.9 & 16.1 & 16.3 \\
\hline Italy & - & 10.7 & 16.7 & 25.8 & 26.2 & 27.0 & 27.3 & 27.8 \\
\hline Netherlands & - & 4.8 & 9.1 & 13.6 & 14.1 & 14.0 & 13.5 & 13.5 \\
\hline New Zealand & - & 6.9 & 9.2 & 11.3 & - & - & - & - \\
\hline Norway & $-3-1.7$ & $6.2-6.9$ & $10.2-10.9$ & 17.9 & 18.5 & 18.9 & 19.4 & 19.7 \\
\hline Spain & - & 10.3 & 17.2 & 22.3 & 22.6 & 22.9 & 23.1 & 23.4 \\
\hline Sweden & $1.5-1.8$ & $6.8-7.8$ & $11.9-12.4$ & 18.3 & 18.9 & 19.2 & 19.8 & 20.0 \\
\hline Switzerland & 1.2 & 4.1 & 6.5 & 6.6 & 6.9 & 7.5 & 8.1 & 8.0 \\
\hline United Kingdom & - & 2.0 & 8.4 & 12.4 & 12.6 & 13.1 & 13.0 & 13.0 \\
\hline USA & $2.1-4.1$ & $2.6-4.6$ & $3.9-6.1$ & 9.4 & 9.0 & 8.8 & 8.8 & 8.9 \\
\hline
\end{tabular}

Source: Schneider $(1997,1999)$.

1) Source: Giles (1999b). 
Table 2: The Size of the Shadow Economy and the Burden of Taxes and Social Security Contributions in OECD countries

\begin{tabular}{|c|c|c|c|c|c|c|c|c|}
\hline Country & $\begin{array}{l}\text { Size of the } \\
\text { shadow } \\
\text { economy (in } \\
\% \text { of GDP) }\end{array}$ & $\begin{array}{c}\text { Value added } \\
\text { tax rate (in } \\
\%)^{1)}\end{array}$ & $\begin{array}{c}\text { Average } \\
\text { direct tax } \\
\text { rate } \\
(\text { in } \%)^{2)}\end{array}$ & $\begin{array}{c}\text { Social security } \\
\text { contributions } \\
\text { by employees } \\
\text { rate } 3 \text { ) } \\
\text { (in \%) }\end{array}$ & $\begin{array}{c}\text { Social security } \\
\text { contributions } \\
\text { by employers } \\
\text { rate }^{3)} \\
\text { (in \%) } \\
\\
1996 \\
\text { (5) } \\
\end{array}$ & 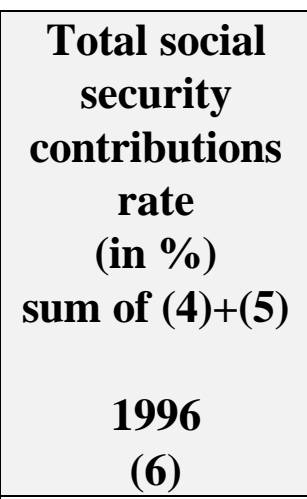 & \begin{tabular}{|c|} 
Total social \\
security \\
contributions + \\
direct tax \\
burden: sum \\
$(4)+(5)+(3)$ \\
(in \%) \\
1996 \\
$(7)$ \\
\end{tabular} & \begin{tabular}{|c} 
Total tax \\
and social \\
security \\
burden: sum \\
$(2)+(3)+$ \\
$(4)+(5)$ \\
1996 \\
$(8)$ \\
\end{tabular} \\
\hline Greece & 28.5 & 18.0 & 11.0 & 15.8 & 27.5 & 43.3 & 54.3 & 72.3 \\
\hline Italy & 27.0 & 19.0 & 12.0 & 9.9 & 32.0 & 41.9 & 53.9 & 72.9 \\
\hline Spain & 22.9 & 16.0 & 13.0 & 6.6 & 31.6 & 38.2 & 51.2 & 67.2 \\
\hline Belgium & 21.9 & 21.0 & 19.0 & 10.0 & 26.0 & 36.0 & 55.0 & 76.0 \\
\hline Sweden & 19.2 & 25.0 & 20.0 & 4.0 & 29.6 & 33.6 & 53.6 & 78.6 \\
\hline Norway & 18.9 & 23.0 & 19.0 & 7.0 & 12.8 & 19.8 & 38.8 & 61.8 \\
\hline Denmark & 18.3 & 25.0 & 36.0 & 9.0 & 0.0 & 9.0 & 45.0 & 70.0 \\
\hline Ireland & 15.9 & 21.0 & 20.0 & 7.2 & 12.3 & 19.5 & 39.5 & 60.5 \\
\hline Canada & 14.6 & 7.0 & 21.0 & 7.0 & 8.0 & 15.0 & 36.0 & 43.0 \\
\hline Germany & 14.5 & 15.0 & 18.0 & 16.1 & 16.1 & 32.2 & 50.2 & 65.2 \\
\hline France & 14.3 & 20.6 & 6.0 & 13.0 & 31.0 & 44.0 & 50.0 & 70.6 \\
\hline Netherlands & 14.0 & 17.5 & 10.0 & 31.0 & 8.8 & 39.8 & 49.8 & 67.3 \\
\hline U.K. & 13.1 & 17.5 & 16.0 & 10.7 & 10.2 & 21.4 & 37.4 & 54.9 \\
\hline USA & 8.8 & 3.0 & 17.0 & 7.6 & 13.8 & 21.4 & 38.4 & 41.4 \\
\hline Austria & 8.3 & 20.0 & 8.0 & 18.2 & 24.2 & 42.4 & 50.4 & 70.4 \\
\hline Switzerland & 7.5 & 6.5 & 10.0 & 11.6 & 11.6 & 23.2 & 33.2 & 39.7 \\
\hline
\end{tabular}

1) Rates of the year 1996; USA: Average sales tax

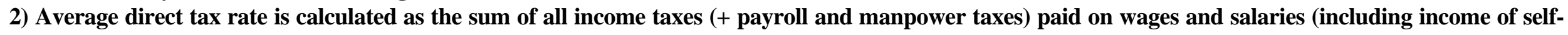
employed) divided by gross labor costs of an average income earner.

3) The rate is calculated on the basis of the annual gross earnings of an average income earner.

Source: Own calculations and OECD-working paper 176, 1997. 
Figure 2.1: Size of the Shadow Economy vs Total Soc. Security

Contributions + Direct Tax Burden*, Year 1996

(Correlation Coefficient with AT $=0,61$, without $\mathrm{AT}=0,72$ )

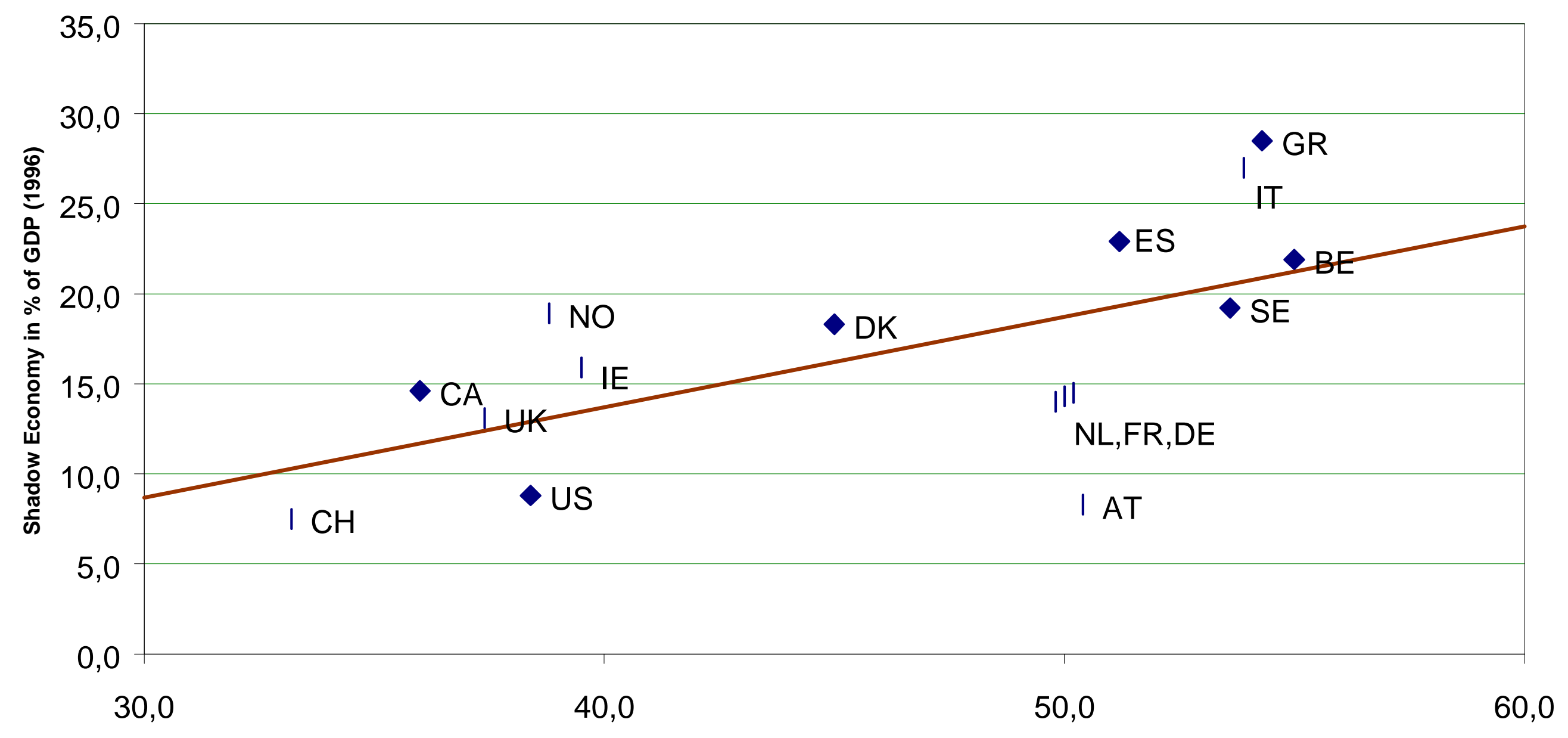

Total Soc. Security Contributions + Direct Tax Burden in \%

* Sum of all income taxes paid on wages and salaries (including income of self-employed) divided by gross labor costs of an average income earner 
Figure 2.2: Size of the Shadow Economy vs

Total Tax ${ }^{\star}$ and Soc. Security Burden, Year 1996

(Correlation Coefficient with AT $=0,62$, without AT $=0,74$ )

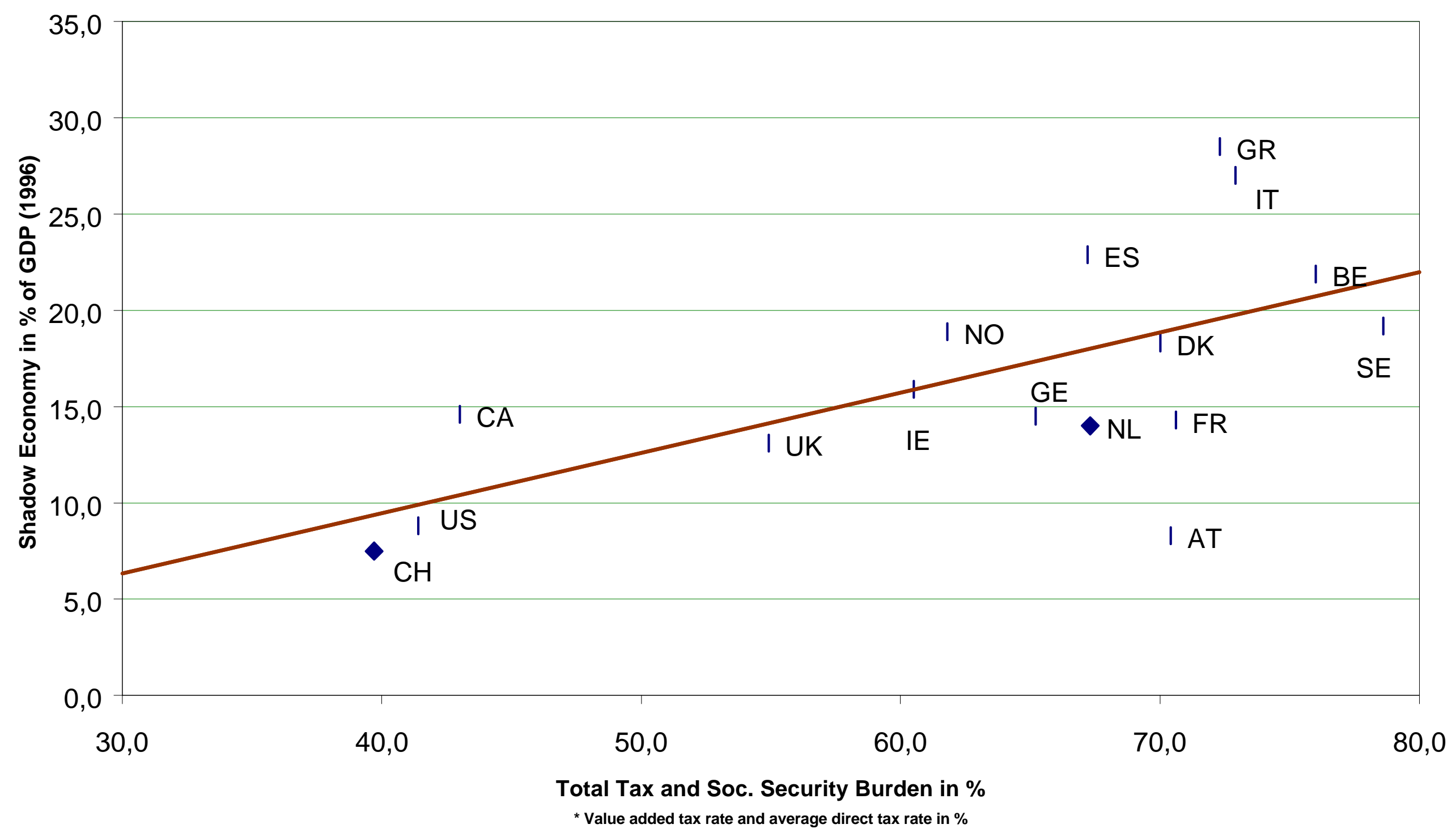


Table 3: Estimates of the Size of the "Shadow Economy Labor Force" in Some OECD Countries 1974-1998

\begin{tabular}{|c|c|c|c|c|}
\hline Countries & Year & $\begin{array}{l}\text { Participants in } \\
1000 \text { people }^{1)}\end{array}$ & $\begin{array}{l}\text { Participants in } \\
\text { \% of Labor } \\
\text { Force }^{2)}\end{array}$ & $\begin{array}{l}\text { Size of the } \\
\text { Shadow Economy } \\
\text { (in \% of GDP) } \\
\text { Currency } \\
\text { Demand } \\
\text { Approach } \\
\end{array}$ \\
\hline Austria & $\begin{array}{l}90-91 \\
97-98\end{array}$ & $\begin{array}{l}300 \\
500\end{array}$ & $\begin{array}{c}9.6 \\
16.0\end{array}$ & $\begin{array}{l}5.47 \\
8.93\end{array}$ \\
\hline Denmark & 1980 & - & 8.3 & 8.6 \\
\hline & 1986 & - & 13.0 & - \\
\hline & 1991 & - & 14.3 & 11.2 \\
\hline & 1994 & - & 15.4 & 17.6 \\
\hline France & $\begin{array}{l}1975-82 \\
1997-98\end{array}$ & $\begin{array}{c}800-1500 \\
1400-3200\end{array}$ & $\begin{array}{c}3.0-6.0 \\
6.0-12.0\end{array}$ & $\begin{array}{c}6.9 \\
14.7\end{array}$ \\
\hline Germany & $\begin{array}{r}1974-82 \\
1997-98 \\
\end{array}$ & $\begin{array}{c}2000-3000 \\
5000\end{array}$ & $\begin{array}{c}8.0-12.0 \\
22.0\end{array}$ & $\begin{array}{r}10.6 \\
14.7 \\
\end{array}$ \\
\hline Italy & $\begin{array}{r}1979 \\
1997\end{array}$ & $\begin{array}{r}4000-7000 \\
6600-11400\end{array}$ & $\begin{array}{l}20.0-35.0 \\
30.0-48.0\end{array}$ & $\begin{array}{r}16.7 \\
\\
27.3\end{array}$ \\
\hline Spain & $\begin{array}{l}1979-80 \\
1997-98\end{array}$ & $\begin{array}{l}1250-3500 \\
1500-4200\end{array}$ & $\begin{array}{c}9.6-26.5 \\
11.5-32.3\end{array}$ & $\begin{array}{l}19.0 \\
23.1\end{array}$ \\
\hline Sweden & $\begin{array}{l}1978 \\
1997\end{array}$ & $\begin{array}{l}750 \\
1150\end{array}$ & $\begin{array}{c}13.0-14.0 \\
19.8\end{array}$ & $\begin{array}{l}13.0 \\
19.8\end{array}$ \\
\hline $\begin{array}{c}\text { European } \\
\text { Union }\end{array}$ & $\begin{array}{c}1978 \\
1997-98\end{array}$ & $\begin{array}{l}10000 \\
20000\end{array}$ & - & 14.5 \\
\hline$O E C D$ & $\begin{array}{c}1978 \\
1997-98\end{array}$ & $\begin{array}{l}16000 \\
35000\end{array}$ & - & 15.0 \\
\hline
\end{tabular}

1) Estimated full-time jobs, including unregistered workers, illegal immigrants, and second jobs. The estimations are based either on surveys (e.g. Denmark) or on a calculation using the valueadded values of the shadow economy (subtracting all material inputs) and assuming certain average values of earnings paid per hour in the shadow economy.

2) In percent of the population aged 20-69. In Denmark: In percent of the population aged 20-69, survey method (\% heavily engaged in shadow economy activities).

Source: Schneider and Enste (2000). 


\begin{tabular}{|c|c|c|}
\hline \multirow[t]{2}{*}{ Independent Variables } & \multicolumn{2}{|c|}{$\begin{array}{c}\text { Dependent Variable: Real Currency } \\
\text { per Capita, In (CURt/POPt) } \\
\text { Estimation Period }\end{array}$} \\
\hline & $1956-1998$ & $1956-1990$ \\
\hline $\begin{array}{l}\text { Lagged Dependent Variable } \\
\ln (\text { CUR t-1 / POP t-1) }\end{array}$ & $\begin{array}{l}0.641 * * \\
(10.93)\end{array}$ & $\begin{array}{l}0.673 * * \\
(11.87)\end{array}$ \\
\hline $\begin{array}{l}\text { Real Consumption per capita } \\
\ln \left(\mathrm{C}_{\mathrm{t}} / \mathrm{POP} \mathrm{t}\right)\end{array}$ & $\begin{array}{l}0.734 * * \\
(6.53)\end{array}$ & $\begin{array}{l}0.749 * * \\
(6.09)\end{array}$ \\
\hline $\begin{array}{l}\text { Number of Eurocheque Systems per capita } \\
\ln \left(E S_{t-1} / \text { POP } t-1\right)\end{array}$ & $\begin{array}{l}-0.175 * * \\
(-2.29)\end{array}$ & $\begin{array}{l}-0.204 * \\
(-2.39)\end{array}$ \\
\hline $\begin{array}{l}\text { Real Interest Rate on Bonds } \\
\ln (\operatorname{IR} t)\end{array}$ & $\begin{array}{l}-0.113 * \\
(-2.31)\end{array}$ & $\begin{array}{l}-0.122 * \\
(-2.55)\end{array}$ \\
\hline $\begin{array}{l}\text { Direct Tax Burden (including social security } \\
\text { payments); ln (DIRT t) }\end{array}$ & $\begin{array}{l}0.224 * * \\
(3.80)\end{array}$ & $\begin{array}{l}0.209 * * \\
(3.21)\end{array}$ \\
\hline $\begin{array}{l}\text { Indirect Tax Burden } \\
\ln (\text { INDT } t)\end{array}$ & $\begin{array}{l}0.129 * \\
(2.28)\end{array}$ & $\begin{array}{l}0.119 * \\
(2.02)\end{array}$ \\
\hline $\begin{array}{l}\text { Complexity/"Visibility" of the Tax System } \\
\ln (\text { COMTX } t)\end{array}$ & $\begin{array}{l}0.124 * \\
(2.49)\end{array}$ & $\begin{array}{l}0.119 * * \\
(2.71)\end{array}$ \\
\hline $\begin{array}{l}\text { Intensity of Regulation } \\
\ln (R E G t)\end{array}$ & $\begin{array}{l}0.203 * * \\
(3.36)\end{array}$ & $\begin{array}{l}0.189 * * \\
(2.92)\end{array}$ \\
\hline Constant Term & $\begin{array}{c}-1.05 \\
(0.80)\end{array}$ & $\begin{array}{l}-1.98 \\
(-1.63)\end{array}$ \\
\hline Test Statistics: & & \\
\hline $\begin{array}{l}\mathrm{R}^{2} \\
\text { S.E. } \\
\text { Durbin's h } \\
\text { rho (1) } \\
\text { D.F. } \\
\text { Ex-post Forecast } 1990-1998 \\
\text { RMSE } \\
\text { Theil's U } 1\end{array}$ & $\begin{array}{r}0.990 \\
0.014 \\
1.07 \\
0.21 \\
35 \\
\\
- \\
-\end{array}$ & $\begin{array}{r}0.993 \\
0.015 \\
1.18 \\
0.23 \\
27 \\
\\
1.39 \\
0.39\end{array}$ \\
\hline
\end{tabular}

*) All equations are estimated by an ordinary least-squares procedure using annual data. $\mathrm{R}^{2}$ is the adjusted coefficient of determination (corrected for the degrees of freedom); S.E. shows the standard error of the estimation. Durbin's h is Durbin's h-test against autocorrelation, when a lagged dependent variables used as regressor. Rho (1) is the autocorrelation coefficient of first order. D.F. stands for the degrees of freedom. RMSE is the root mean squared error and Theil's $\mathrm{U} 1$ stands for Theil's inequality coefficient. The term „ $I n$ “ indicates that these variables have been transformed to natural logarithms. Numbers in parentheses below coefficient estimates are t-values. $(*), *$ and $* *$ indicate significance at the $90 \%, 95 \%$ and $99 \%$-level, respectively. Real Currency is defined as cash money held outside banks. 
Table 5: Size of the Austrian Shadow Economy 1)

\begin{tabular}{|c|c|c|c|}
\hline Year & $\begin{array}{c}\text { "Official" Gross } \\
\text { Domestic Production, } \\
\text { real, Bill. AS }\end{array}$ & $\begin{array}{l}\text { Value Added in the } \\
\text { Shadow Economy, } \\
\text { real, Bill AS }\end{array}$ & $\begin{array}{l}\text { Size of the Shadow } \\
\text { Economy in percent } \\
\text { of the, ,official“6 GDP }\end{array}$ \\
\hline 1965 & 440.95 & 5.14 & 1.16 \\
\hline 1966 & 466.20 & 5.69 & 1.22 \\
\hline 1967 & 479.98 & 5.49 & 1.14 \\
\hline 1968 & 502.18 & 6.21 & 1.24 \\
\hline 1969 & 533.44 & 8.31 & 1.56 \\
\hline 1970 & 571.25 & 10.47 & 1.83 \\
\hline 1971 & 600.31 & 9.58 & 1.59 \\
\hline 1972 & 637.69 & 10.41 & 1.63 \\
\hline 1973 & 669.29 & 13.34 & 1.99 \\
\hline 1974 & 695.79 & 12.46 & 1.79 \\
\hline 1975 & 692.84 & 12.02 & 1.73 \\
\hline 1976 & 724.75 & 15.39 & 2.12 \\
\hline 1977 & 756.12 & 18.01 & 2.38 \\
\hline 1978 & 760.23 & 20.06 & 2.63 \\
\hline 1979 & 795.96 & 22.88 & 2.87 \\
\hline 1980 & 820.03 & 24.98 & 3.05 \\
\hline 1981 & 818.58 & 26.96 & 3.29 \\
\hline 1982 & 828.62 & 29.09 & 3.51 \\
\hline 1983 & 845.54 & 31.86 & 3.77 \\
\hline 1984 & 862.66 & 36.38 & 4.22 \\
\hline 1985 & 887.39 & 36.98 & 4.16 \\
\hline 1986 & 904.46 & 39.64 & 4.38 \\
\hline 1987 & 924.84 & 41.22 & 4.46 \\
\hline 1988 & 959.91 & 46.37 & 4.83 \\
\hline 1989 & 1004.09 & 50.89 & 5.07 \\
\hline 1990 & 1061.32 & 54.56 & 5.14 \\
\hline 1991 & 1126.32 & 59.89 & 5.32 \\
\hline 1992 & 1160.37 & 68.23 & 5.88 \\
\hline 1993 & 1181.90 & 74.46 & 6.30 \\
\hline 1994 & 1228.95 & 82.34 & 6.70 \\
\hline 1995 & 1243.89 & 89.56 & 7.20 \\
\hline 1996 & 1273.98 & 105.86 & 8.31 \\
\hline 1997 & 1303.99 & 116.32 & 8.92 \\
\hline 1998 & 1355.50 & 123.62 & 9.12 \\
\hline
\end{tabular}

1) Assumptions made for the calculation of the shadow economy:

(i) All transactions in the shadow economy are made in cash. (ii) Direct and indirect tax burdens, the complexity of the tax system and the intensity of regulations are the reasons for working in the shadow economy. (iii) In 1960 the shadow economy did not exist. (iv) The velocity of currency is the same in the shadow economy as in the official economy and is calculated by dividing total income by M1. (v) For the calculation, first the currency-demand equation from table 4 is used. 
Table 6: The Influence of Changing Tax Systems on the Size and Growth of the Austrian Shadow Economy

\begin{tabular}{|c|c|c|c|c|c|}
\hline \multirow[b]{2}{*}{ Year } & \multirow[b]{2}{*}{$\begin{array}{l}\text { Size of the } \\
\text { Shadow } \\
\text { Economy } \\
\text { Bill. AS }\end{array}$} & \multicolumn{4}{|c|}{$\begin{array}{c}\text { Amount of the Shadow Economy Attributed } \\
\text { to }\end{array}$} \\
\hline & & $\begin{array}{c}\text { Direct Tax } \\
\text { Burden } \\
\text { Bill. AS }\end{array}$ & $\begin{array}{c}\begin{array}{c}\text { Indirect } \\
\text { Tax } \\
\text { Burden }\end{array} \\
\text { Bill. AS }\end{array}$ & $\begin{array}{c}\text { Complexity } \\
\text { of the Tax } \\
\text { System } \\
\text { Bill. AS }\end{array}$ & $\begin{array}{c}\text { Intensity of } \\
\text { Regulation } \\
\text { Bill. AS }\end{array}$ \\
\hline $\begin{array}{r}\text { Case (i) } \\
1972 \\
1973\end{array}$ & $\begin{array}{l}10.41 \\
13.34\end{array}$ & $\begin{array}{l}5.58 \\
6.82\end{array}$ & $\begin{array}{l}1.45 \\
2.20\end{array}$ & $\begin{array}{l}2.37 \\
3.24\end{array}$ & $\begin{array}{l}1.01 \\
1.08\end{array}$ \\
\hline $\begin{array}{l}\text { Diff. (73-72) } \\
\text { (rel. weight) }\end{array}$ & $\begin{array}{c}2.93 \\
(100.0 \%)\end{array}$ & $\begin{array}{c}1.24 \\
(42.3 \%)\end{array}$ & $\begin{array}{c}0.75 \\
(25.6 \%)\end{array}$ & $\begin{array}{c}0.87 \\
(29.7 \%)\end{array}$ & $\begin{array}{c}0.07 \\
(2.4 \%)\end{array}$ \\
\hline $\begin{array}{r}\text { Case (ii) } \\
1983 \\
1984\end{array}$ & $\begin{array}{l}31.86 \\
36.38\end{array}$ & $\begin{array}{l}13.48 \\
16.12\end{array}$ & $\begin{array}{l}7.74 \\
9.57\end{array}$ & $\begin{array}{l}5.19 \\
5.16\end{array}$ & $\begin{array}{l}5.45 \\
5.53\end{array}$ \\
\hline $\begin{array}{l}\text { Diff. (84-83) } \\
\text { (rel. weight) }\end{array}$ & $\begin{array}{c}4.52 \\
(100.0 \%) \\
\end{array}$ & $\begin{array}{c}2.64 \\
(58.4 \%) \\
\end{array}$ & $\begin{array}{c}1.83 \\
(40.5 \%)\end{array}$ & $\begin{array}{l}-0.03 \\
(-0.7 \%)\end{array}$ & $\begin{array}{c}0.08 \\
(1.8 \%)\end{array}$ \\
\hline $\begin{array}{r}\text { Case (iii) } \\
1988 \\
1989\end{array}$ & $\begin{array}{l}46.37 \\
50.89\end{array}$ & $\begin{array}{l}19.01 \\
17.86\end{array}$ & $\begin{array}{l}11.27 \\
12.21\end{array}$ & $\begin{array}{l}6.12 \\
8.90\end{array}$ & $\begin{array}{r}9.97 \\
11.91\end{array}$ \\
\hline $\begin{array}{l}\text { Diff.(89-88) } \\
\text { (rel. weight) }\end{array}$ & $\begin{array}{c}4.52 \\
(100.0 \%)\end{array}$ & $\begin{array}{c}-1.15 \\
(-25.4 \%)\end{array}$ & $\begin{array}{c}0.94 \\
(20.8 \%)\end{array}$ & $\begin{array}{c}2.79 \\
(61.7 \%)\end{array}$ & $\begin{array}{c}1.94 \\
(42.9 \%)\end{array}$ \\
\hline
\end{tabular}


Table 7: Breakdown of the Shadow Economy According to the Four Causes

\begin{tabular}{|c|c|c|c|c|}
\hline \multirow[b]{2}{*}{ Year } & \multicolumn{4}{|c|}{ The Shadow Economy in Percent Share of } \\
\hline & $\begin{array}{c}\text { Direct Tax } \\
\text { Burden } \\
\%\end{array}$ & $\begin{array}{c}\text { Indirect Tax } \\
\text { Burden } \\
\%\end{array}$ & $\begin{array}{c}\text { Complexity of } \\
\text { the Tax System } \\
\%\end{array}$ & $\begin{array}{c}\text { Intensity of } \\
\text { Regulation } \\
\%\end{array}$ \\
\hline 1965 & 51.2 & 12.1 & 25.9 & 9.8 \\
\hline 1966 & 51.8 & 12.4 & 25.3 & 11.1 \\
\hline 1967 & 49.3 & 11.2 & 26.1 & 13.4 \\
\hline 1968 & 49.6 & 11.9 & 25.3 & 13.2 \\
\hline 1969 & 50.9 & 12.6 & 24.6 & 11.9 \\
\hline 1970 & 51.3 & 13.5 & 23.4 & 11.8 \\
\hline 1971 & 52.3 & 13.3 & 23.0 & 11.4 \\
\hline 1972 & 53.6 & 13.9 & 22.8 & 9.7 \\
\hline 1973 & 51.1 & 16.5 & 24.3 & 8.1 \\
\hline 1974 & 52.0 & 16.0 & 24.0 & 8.0 \\
\hline 1975 & 50.9 & 15.9 & 23.4 & 9.8 \\
\hline 1976 & 51.4 & 18.4 & 21.2 & 9.0 \\
\hline 1977 & 51.0 & 20.1 & 20.6 & 8.3 \\
\hline 1978 & 49.6 & 22.0 & 18.7 & 9.7 \\
\hline 1979 & 47.6 & 21.9 & 18.8 & 11.7 \\
\hline 1980 & 46.3 & 21.6 & 17.9 & 14.2 \\
\hline 1981 & 45.0 & 23.3 & 17.0 & 14.4 \\
\hline 1982 & 42.2 & 24.9 & 17.1 & 15.8 \\
\hline 1983 & 42.3 & 24.3 & 16.3 & 17.1 \\
\hline 1984 & 44.3 & 26.3 & 14.2 & 15.2 \\
\hline 1985 & 44.0 & 25.2 & 15.2 & 15.6 \\
\hline 1986 & 43.1 & 25.2 & 14.1 & 17.6 \\
\hline 1987 & 40.9 & 24.0 & 13.7 & 21.4 \\
\hline 1988 & 41.0 & 24.3 & 13.2 & 21.5 \\
\hline 1989 & 35.1 & 25.6 & 17.1 & 22.2 \\
\hline 1990 & 34.6 & 25.1 & 17.3 & 23.0 \\
\hline 1991 & 34.1 & 25.4 & 17.0 & 23.5 \\
\hline 1992 & 33.1 & 25.6 & 17.4 & 23.9 \\
\hline 1993 & 31.9 & 25.9 & 17.9 & 24.3 \\
\hline 1994 & 30.5 & 26.2 & 18.2 & 25.1 \\
\hline 1995 & 28.7 & 26.6 & 18.7 & 26.0 \\
\hline 1996 & 29.1 & 26.6 & 18.2 & 26.1 \\
\hline 1997 & 29.3 & 26.7 & 17.7 & 26.3 \\
\hline 1998 & 29.5 & 26.8 & 17.7 & 26.0 \\
\hline
\end{tabular}




\section{References}

Alm, J., 1988, Compliance Costs and the Tax Avoidance Tax Evasion Decision, Public Finance Quarterly, 16, pp. 31 - 66.

Blades, D., 1982, The Hidden Economy and the National Accounts, OECD Economic Outlook, Paris, pp. 28 - 45.

Bös, D., 1975, Die finanzpolitische Entwicklung in Österreich 1971-1974, Finanzarchiv, N.F. 33, pp. 305-338.

Boeschoten, W. C., and M. M. G. Fase, 1984, The Volume of Payments and the Informal Economy in the Netherlands 1965 - 1982, Dordrecht: Kluwer-Publishing Comany.

Cagan, P., 1958, The Demand for Currency Relative to the Total Money Supply, Journal of Political Economy, 66, pp. 303 - 328.

Clotefelter, C. T. C., 1976, Public Spending for Higher Education: An Empirical Test of Two Hypotheses, Public Finance, 31, pp. 177 - 195.

Clotefelter, C. T. C., 1983, Tax Evasion and Tax Rates: An Analysis of Individual Returns, Review of Economics and Statistics, 65, pp. 363 373.

Franz, A., 1985, Estimates of the Hidden Economy in Austria on the Basis of Official Statistics, Review of Income and Wealth, 31, pp. 325 - 336.

Frey, B. S., and W. W. Pommerehne, 1984, The Hidden Economy: State and Prospects for Measurement, Review of Income and Wealth, 30, pp. 1 23.

Frey, B. S., and H. Weck-Hannemann, 1984, The Hidden Economy as an „Unobserved“ Variable, European Economic Review, 26/1, pp. 33 - 53.

Friedman, E., Johnson, F. Kaufmann, D. and Zoido-Lobatón P. (1999), Dodging the Grabbing Hand: The Determinance of Unofficial Activity in 69 countries, Discussionpaper, Washington D.C.: World Bank.

Garcia, G., 1978, The Currency Ratio and the Suberranean Economy, Financial Analysis Journal, 34 (6), pp. 64 - 66.

Genser, B., and R. Holzmann, 1987, Die finanzpolitische Entwicklung in Österreich 1985 - 1986, Finanzarchiv, N. F. 45, pp. 500 - 526.

Genser, B., and R. Holzmann, 1990, Die finanzpolitische Entwicklung in Österreich 1987 - 1988, Finanzarchiv, N. F. 48, pp. 143 - 168.

Giles, D., E.A. (1999a): Measuring the hidden economy: Implications for econometric modelling, The Economic Journal, 109/456, pp.370-380.

Giles, D., E.A. (1999b): Modelling the hidden economy in the tax cape in New Zealand, Working paper, Department of Economics, University of Victoria, Canada

Gutmann, P. M., 1977, The Subterranean Economy, Financial Analysis Journal, 33 (6), pp. $26-27,34$.

Hill, R. and M. Kabir (1996): Tax rates, the tax mix, and the growth of the underground economy in Canada: What can we infer?, Canadian Tax Journal/Revue Fiscale Canadienne 44/6, pp.1552-1583. 
Hofreither, M. F., and F. Schneider, 1987, Die Erfassung der Schattenwirtschaft durch den Bargeldansatz - plausible Ergebnisse mittels unzulässiger Methode?, Wirtschaftspolitische Blätter, 34, pp. 99 - 118.

Hofreither, M. F., and F. Schneider, 1989, Gibt es ein politisches Interesse die Schattenwirtschaft zu bekämpfen? Ein Versuch politisch-ökonomischer Erklärung, in: E. Boettcher, P. Herder-Dornreich, and K. E. Schenk (eds.), Jahrbuch für Neue Politische Ökonomie, 8, Tübingen, pp. 62 87.

Isachsen, A., and S. Strom, 1980, The Hidden Economy: The Labor Market and Tax Evasion, Scandinavian Journal of Economics, 82, pp. 304 - 311.

Isachsen, A., and S. Strom, 1985, The Size and Growth of the Hidden Economy in Norway, Review of Income and Wealth, 31, pp. 21 - 38.

Johnson, S., Kaufmann, D. and Shleifer, A. (1997), The Unofficial Economy in Transition, Brookings Paper on Economic Activity, Fall, Washington D.C.

Johnson, S., Kaufmann, D. and Zoido-Lobatón P. (1998), Regulatory Discretion and the Unofficial Economy, The American Economic Review, 88/2, pp. 387 - 392.

Kirchgässner, G., 1983, Size and Development of the West-German Shadow Economy 1955 - 1980, Zeitschrift für die gesamte Staatswissenschaft, 139, pp. $197-214$.

Kirchgässner, G., 1984, Verfahren zur Erfassung des in der Schattenwirtschaft erarbeiteten Sozialproduktes, Allgemeines Statistisches Archiv, 68, pp. $378-405$.

Klovland, J., 1984, Tax Evasion and the Demand for Currency in Norway and Sweden. Is there a Hidden Relationship?, Scandinavian Journal of Economics, 86, pp. 423 - 439.

Lipert, O. and Walker, M. (eds.) (1997), The Underground Economy: Global Evidence of Size and Impact, Vancouver, The Fraser Institute.

Mooslechner, P., 1985, Der monetäre Ansatz zur Schattenwirtschaft - Eine empirische Illustration anhand österreichischer Daten, in: J. Skolka (ed.),

Die andere Wirtschaft: Schwarzarbeit und Do-It-Yourself in Österreich, Vienna, pp. 101 - 119.

Neck, R. and F. Schneider, 1993, The Development of the Shadow Economy Under Changing Tax Systems and Structures, Finanzarchiv, 50/3, pp. $344-369$.

Neck, R., F. Schneider and M. F. Hofreither, 1989, The Consequences of Progressive Income Taxation for the Shadow Economy: Some Theoretical Considerations, in: D. Bös and B. Felderer (eds.), The Political Economy of Progressive Taxation, Heidelber, pp. 149 - 176.

OECD, 1997, Taxation and Economic Performance, by Leebtritz, W, Thornton, J. and Bibbee, A., Economics Department, Working Paper 176, Paris, 1997.

Park, T., 1979, Reconciliation between Personal Income and Taxable Income, 1947 - 1977, Bureau of Economic Analysis, Washington, D. C. 
Pommerehne, W. W., 1983, Steuerhinterziehung und Schwarzarbeit als Grenzen der Staatstätigkeit, Schweizerische Zeitschrift für Volkswirtschaft und Statistik, 119, pp. $261-284$.

Pommerehne, W. W., 1986, Was wissen wir eigentlich über Steuerhinterziehung?, Rivista Internazionale di Science Economiche e Commerciali, 35, pp. $230-262$.

Pommerehne, W. W., and F. Schneider, 1985, The Decline of Productivity Growth and the Rise of the Shadow Economy in the U.S.; Working Paper, University of Aarhus.

Pozo, Susan (ed.), 1996, Exploring the underground economy: Studies of illegal and unreported activity, Michigan: W.E. Upjohn, Institute for Employment Research.

Schneider, F., 1986, Estimating the Size of the Danish Shadow Economy Using the Currency Demand Approach: An Attempt, Scandinavian Journal of Economics, 88, pp. 643 - 668.

Schneider, F., 1994, Determinanten der Steuerhinterziehung der Schwarzarbeit im internationalen Vergleich, in: Smekal, Ch. und Theurl, E. (eds.), Stand und Entwicklung der Finanzpsychologie, Baden-Baden: Nomos Verlag, pp. 247 - 288.

Schneider, F., 1997, The Shadow Economies of Western Europe, Journal of The Institut of Economic Affairs, 17/3, pp. $42-48$

Schneider, F., 1999, Ist Schwarzarbeit ein Volkssport geworden? Ein internationaler Vergleich des Ausmaßes der Schwarzarbeit von 1970-97, in: Lamnek, S. and Luedtke, J. (eds.), Der Sozialstaat zwischen Markt und Hedonismus, Obladen (West Germany): Luedtke and Budrich publishing company, pp.293-318.

Schneider, F., M. F. Hofreither and R. Neck, 1989, The Consequences of a Changing Shadow Economy for the 'Official' Economy: Some Empirical Results for Austria, in: D. Bös and B. Felderer (eds.), The Political Economy of Progressive Taxation, Heidelberg, Springer Publishing Company, pp. $181-211$.

Schneider, F. and Enste, D., 2000, Shadow Economies Around the World: Sizes, Causes and Consequences, forthcoming in The Journal of Economic Literature, March 2000.

Tanzi, V., 1980, The Underground Economy in the United States: Estimates and Implications, Banca Nazionale del Lavoro Quarterly, 135, pp. 427 453.

Tanzi, V., 1983, The Underground Economy in the United States: Annual Estimates, 1930 - 1980, IMF-Staff Papers, 30, pp. 238 - 305.

Tanzi, V., 1999, Uses and Abuses of Estimates of the Underground Economy, The Economic Journal 109/456, pp.338-340.

Thomas, J.J., 1986, The underground economy in the United States: A comment on Tanzi, IMF-Staff Papers Vol.33, No. 4, pp.782-789.

Thomas, J.J., 1992, Informal economic activity, LSE, Handbooks in Economics, London: Harvester Wheatsheaf. 
Thomas, J.J., 1999, Quantifying the Black Economy: 'Measurement without Theory' Yet Again?, The Economic Journal 109/456, pp.381-389.

Weck, H., 1983, Schattenwirtschaft: Eine Möglichkeit zur Einschränkung der öffentlichen Verwaltung?, Bern: Verlag Peter Lang Publishing Company.

Wagner, R. E., 1976, Revenue Structure, Fiscal Illusion and Budgetary Choice, Public Choice, 25, pp. 45 - 61. 